NASA

Technical Memorandum 8162?
AVRADCOM

Technical Report 81-C-3

\title{
Design of Spur Gears for Improved Efficiency
}

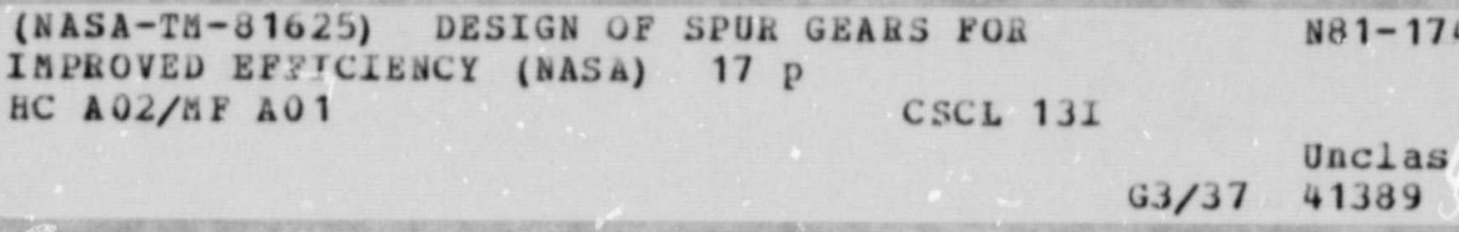

Neil E. Anderson

Propulsion Laboratory

AVRADCOM Research and Technology Laboratories Lewis Research Center

and

Stuart H. Loewenthal Lewis Research Center Cleveland, Ohio

Prepared for the

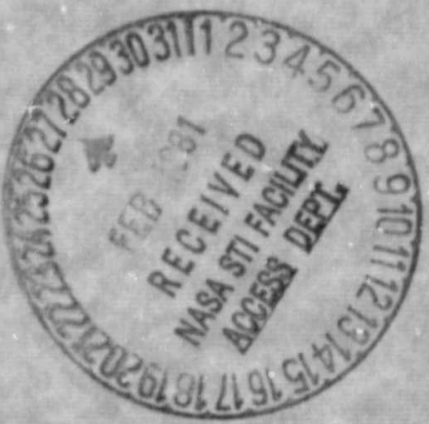

ASME Western Design Engineering Conference Anaheim, California, December 9-11, 1980 and the ASME Design Engineering Conference Chicago, Illinois, April $2 \% 30,1981$ 


\title{
DEST GN OF SPUR GEARS FOR IMPROVED EFFICIENCY
}

\author{
by Nef1 E. Anderson* \\ Propulsion Laboratory \\ AVRADCOM Research and Technology Laboratories \\ Lewis kesearch Center \\ Cleveland, Ohio \\ and
}

Stuart H. Loewentha I*

Lewis Research Center

cleveland, ohio

\section{INTRODUCTION}

Generally the geometry of a gear set is designed for the best compromir- of tooth strength, surface durability and cost. After checking scoring criteria a power loss calculation might also ive made, possibly as an afterthought. The gear designer is either not aware or does not fully appreciate that certain gear geometric variables can significantly affect the power loss of the gearset being designed. For example, as shown in ari earlier work by the authors [1] a change in diametral pitch of 32 to 4 can decrease peak effim ciency from 99.8 to 99.4 percent for a $10 \mathrm{~cm}(4.0$ in.) pinion gearset under certain operating conditions. Although at first glance this appears to be of little significance, such a change represents at 200 percent change in power loss!

A study of the effects of a wide range of gear geometric and operating conditions on gear efficiency has not been available prior to the work of [1]. A1though many methods have been proposed to estimate gear efficiency [2-6] they are not refined to the point that the effects of each gear geometric variable and operating condition on the overall gearset eff $i$ ciency can be evaluated. Furthermore, most of these methods seriously underestimate gear system power losses at less than full load since they neglect speed dependent losses, that is, the losses associated with forming an elastohydrodynamic film (rolling traction), gear windage a support bearing losses. These speeddependent losst contrioute significantly to the c'mulative power consumption of many machines which oferate at less than full power levels much of the till. Perhaps the most complete spur gear efficienc analysis presented prior to the present method is re- ported in [6]. In [6] instantaneous values of sliding and rolling power loss were integrated over the path of contact and averaged. The effects of gear geometry were incorporated into this analysis.

The method of [7] included not only sliding and rolling traction gear losses but also considered the effects of windage and rolling element bearing losses as well.

In order to determine gear mesh losses with the method of [7] it is necessary either to perform a numerical integration or to calculate and sum the power loss at three points along the path of contact. It therefore became the objective of the present study to (1) develop for design purposes a power loss expression that need be evaluated at only one point along the path of contact; (2) \$0 compare this expression with the numerically evaluated expression of [7]; (3) to use this analysis to illustrate which gear geometric and operating variables lead to the highest efficiencies, and (4) illustrate the use of the method with a design example.

\section{SYMBOLS}

$\mathrm{C}_{\mathrm{S}} \quad$ support-bearing basic static capacity, n ( Ibf)

$\mathrm{C}_{1}$ constant used in Eg. (1): $2 \times 10^{-3}$ (SI units); $3.03 \times 10^{-4}$ (English units)

$\mathrm{C}_{2}$ constant used in Eq. (2): $9 \times 10^{4}$ (SI units); 1.970 (English units)

$\mathrm{C}_{3} \quad$ constant used in Eqs. $(3,4): 2.82 \times 10^{-7}$ (SI units); $4.05 \times 10^{-13^{\prime}}$ (English units)

$\mathrm{C}_{4} \quad$ constant used in Eqs. $(3,4): 0.019$ (SI units); $2.86 \times 10^{9}$ (English units)

$\mathrm{C}_{5} \quad$ constant used in Eg. (5): $2.10 \times 10^{-4}$ (SI units); $3.18 \times 10^{-4}$ (English units)

\footnotetext{
${ }^{\star}$ Member ASME.
} 


\begin{tabular}{|c|c|}
\hline$c_{6}$ & $\begin{array}{c}\text { constant used in Eg. (7): } 9.79 \times 10^{-2} \text { (SI } \\
\text { units): } 2.91 \times 10^{-2} \text { (English urits) }\end{array}$ \\
\hline$C_{7}$ & $\begin{array}{l}\text { constant used in Eq. (7): } 24.1 \text { (SI units); } \\
3.49 \times 10^{-3} \text { (English units) }\end{array}$ \\
\hline $\mathrm{C}_{8}$ & $\begin{array}{l}\text { constant used in Eq. (9): } 0.013 \text { (SI units); } \\
0.5 \text { (English units) }\end{array}$ \\
\hline $\mathrm{C}_{g}$ & $\begin{array}{l}\text { constant used in Eq. (13): } 29,66 \text { (SI } \\
\text { units); } 45.94 \text { (English units) }\end{array}$ \\
\hline$c_{10}$ & $\begin{array}{c}\text { constant used in Eq. (15): } 2.051 \times 10^{-7} \text { (SI } \\
\text { units); } 4.34 \times 10^{-3} \text { (English units) }\end{array}$ \\
\hline$c_{11}$ & $\begin{array}{l}\text { constant used in Eq. (16): } 39.37 \text { (SI } \\
\text { units); 1.0 (English its) }\end{array}$ \\
\hline$c_{12}$ & $\begin{array}{l}\text { constant used in Eq. (8): } 1.45 \times 10^{-4} \text { (SI } \\
\text { units); } 1.0 \text { (English units) }\end{array}$ \\
\hline D & pitch circle diameter, $m\left(i n_{.}\right)$ \\
\hline$D_{m}$ & bearing pitch diameter, $m$ (in.) \\
\hline FST & static equivalent bearing load, N (Ibf) \\
\hline $\boldsymbol{I}$ & face width of tooth, $m(i n)$. \\
\hline$f_{0}$ & ball-bearing lubrication factor \\
\hline$f$ & coefficient of friction \\
\hline $\bar{h}$ & isothermal central film thickness, m (in.) \\
\hline K & gear capacity factor \\
\hline${ }^{\ell} T$ & length of path of contact, $m$ (in.) \\
\hline$M$ & bearing friction torque, $\mathrm{N}-\mathrm{m}$ (in-lbf) \\
\hline$M_{L}$ & $\begin{array}{l}\text { load-dependent part of bearing friction } \\
\text { torque, } N-m \text { (in-lbf) }\end{array}$ \\
\hline My & $\begin{array}{l}\text { viscous part of bearing friction torque, } \\
N-m \text { (in-1bf) }\end{array}$ \\
\hline$m_{g}$ & gear ratio, $N_{g} / N_{p}$ \\
\hline$N$ & number of gear teeth \\
\hline $\mathcal{N}$ & efficiency, percent \\
\hline$n$ & rotational speed, $\mathrm{rpm}$ \\
\hline $\mathbf{p}$ & power loss \\
\hline$P_{B R G}$ & $\begin{array}{l}\text { total power loss due to rolling-element } \\
\text { support bearings, } \mathrm{kW}(\mathrm{hp})\end{array}$ \\
\hline$\overline{\mathrm{P}}_{\mathrm{R}}$ & power loss due to rolling traction, $\mathrm{kW}$ (hp) \\
\hline$\overline{\mathrm{P}}_{S}$ & power loss due to tooth sliding, $\mathrm{kW}$ (hp) \\
\hline$P_{W}$ & power loss due so windage, $\mathrm{kW}(\mathrm{hp})$ \\
\hline $\mathscr{P}$ & diamentral pitch \\
\hline$R$ & $\begin{array}{l}\text { pitch circle radius or radius in gerieral, } \\
m(i n .)\end{array}$ \\
\hline$R_{e q}$ & equivalent rolling \\
\hline
\end{tabular}

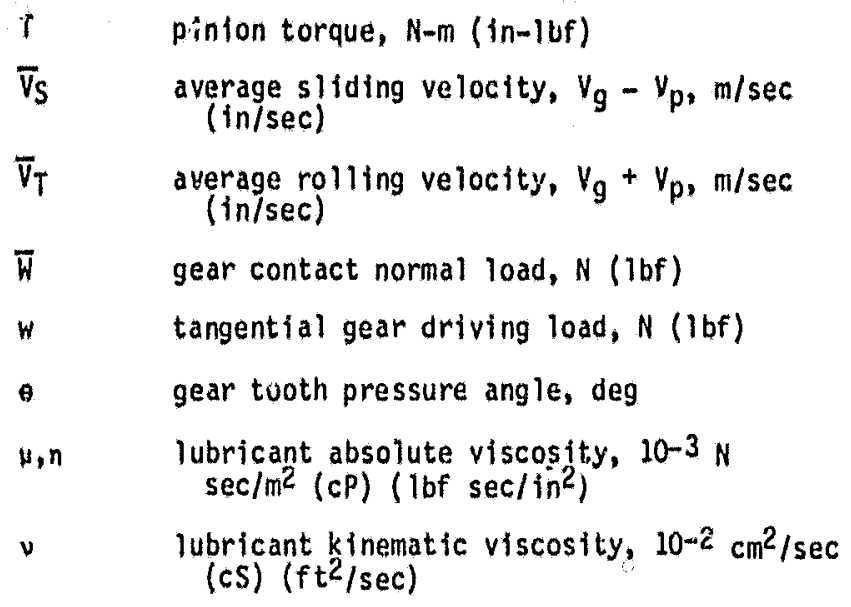

Subscripts:

$\begin{array}{ll}g & \text { gear } \\ \text { IN } & \text { input } \\ p & \text { pinion } \\ R & \text { rolling } \\ S & \text { sliding } \\ \text { TOT } & \text { total } \\ 0 & \text { ambient conditions }\end{array}$

GEAR POWER LOSS ANALYSIS

The method presented here, following that of [7], considers four major sources of gear system power loss: sliding, rolling, windage and suppost bearing losses. It is applicable to spur gears of standard tooth proportions in which the gears are jet or splash lubricated. No accounting has been made for churning losses of gears running submerged in oil. The analy sis considers sliding losses which are the result of friction forces developed as teeth slide across 0 ? another. Rolling losses are generated in the formation of an elastohydrodynamic (EHD) film, that is, as 0 il is squeezed between gear teeth and subsequent ly pressurized. In addition to gear sliding and icilling losses an expression was developed to account for gear windage based on disc drag data presented in $[8,9]$. Support ball bearing losses were included using a weli-known method reported in [10].

In [7] the mesh losses were calculated by numerically integrating the sliding and rolling losses over the path of contact. In this analys is the average power losses across the path of contact are calculated algebraically from the average sliding and rolling velocity of the mesh. A simple tooth loading diagram shown in Fig. 1 was assumed. The effect of tooth load sharing was included. The frictional sliding loss was based on disc machine data generated by Benedict and Kelley [11]. Their friction coefficient expression, which fit this data, is corisidered to be applicable to gear sliding loss calculations in the EHD lubrication regime where some asperity contact eccurs, which is the common case.

As in [7], rolling losses were taken to be directly proportional to the EHD central film thickness following [12]. Gear tooth film thickness was calcu- 
lated by the method of Hamrock [13]. In [7], film thickness was adjustad fer themal effects using Cheng's thennal reduction factor [19]. This factor causes the EHd film thickness to reach some limiting value with inereasing speed, However, in the interest of simplicity, thermal effects, though potentially important at high speeds and low loads, will not be ineluded in the sinpliffied method to be presented.

In [7] a numerical integration method was used to compute power loss over the path of contect and was later silip? fied to an interval calculation. Here the method will be further simplified to a single loss expression representing the average loss across the path of contact. This is accomplished by choosing a single point along the path of contact where average sliding and rolling velocities occur to evaluate the loss expressions. In Fig. 2 a comparison of the instantaneous and average velocities as well as the in= stantaneous and average power losses are shown. The point at which the power loss equations are evaluated is at \& $T / 4$, where the average value of sliding and rolling veloctties for the mesh occur. Sliding and rolling losses can be found from:

$$
\begin{aligned}
& \mathrm{P}_{\mathrm{S}}=\mathrm{c}_{1} / \mathrm{WV} \\
& \left(P_{R} \circ C_{2} \pi V_{T} F(R)\right.
\end{aligned}
$$

where the variables used in triest expressions ate dem scribed in the design example presented in a later section.

The simplif igd values of power loss, lso shown in Fig. 2, approximate the area under the instantance ous loss curves to a hiph degree of accuracy and thus provide an accurate, simple method to determine the mesti losses. The sinplified expression was found to be within 0.1 percentage points of the numerically integrated solution of [7] for the range of variables presented later in this work. The only exception to this is at extremel light laads ( $k-f$ actor of 10$)$ and high speed (greater than $40 \mathrm{~m} / \mathrm{sec}$ ) where under certain conditions the error can rise to 1 percentage point. This is due to the omission of a themmal correction factor to limit EHD film thickness, hence rolling power loss, at high speeds. If such operating conditions are of interest then it is suggested that a themal EHD reduction factor such as that used in [7] be incorporated inte the analysis, In addition to the mesh losses, an expression for gear windage loss was also developed in [7] from experimental data on turbine disc wiadage losses. To accuunt for she oily atmosphere within the gearbox the density and viscosity of the gearbox atmosphere were corrected to reflect a 34.25 part air to 1 part oil colubination as in [15]. Constant values for air density and viscosity at $339 \mathrm{~K}\left(150^{\circ} \mathrm{F}\right)$ and oil specific gravity of 0,9 were assumed. The expressiuns for pimion and gear windaye were found to be :

$$
\begin{aligned}
& P_{W, p}=C_{3}\left(1+2.3 \frac{g}{R_{p}}\right) n_{p}^{2.8} B_{p}^{4.6}\left(0.028 \mu+C_{q}\right)^{1.2} \\
& P_{W, 9}=C_{3}\left(1+2.3 \frac{g}{R_{g}}\right)\left(\frac{n_{p}}{n g}\right)^{2.8} R_{g}^{4.6}\left(0.028 \mu+c_{4}\right)^{0.2}
\end{aligned}
$$

Support bearing loss from the approx intse mathod of Harris [10] was also included in [7]. A stradale mounted deep groove ball bearing arrangement was as sunted for comparison purposes. The deep groove ball bearing losses are function of the bearing pitch diameter, static capacity, lubricant viscosity, shaft speed and bearing load. These equations are:

$$
P_{B R G}=C_{b}\left(M_{p} n_{p}+M_{g} r_{g}\right)
$$

$M$ is a torque loss consisting of a load-dependent (M) and a viscous term (MV). For a deep groove batl bearing:

$$
\begin{aligned}
& M_{L}=0.0009 \frac{F s T^{1.55}}{c_{s}^{0.55}} D_{m} \\
& M_{V}=\left\{\begin{array}{cc}
c_{6} f_{0}(u n)^{2 / 3} D_{m}^{3} & \text { for }(u n)>2000 \\
c_{7} f_{0} 0_{m}^{3} & \text { for }(u n) \leq 2000
\end{array}\right\}
\end{aligned}
$$

\section{Design Exanule}

The following is a step-by-step example of a power loss calculation using the simplified method developed in this investigation. The given geometry and onnerting conditions are for the example shown in Fig, 2 .

Gear data: $\mathrm{N}_{\mathrm{R}}, 48 ; \mathrm{N}_{9}, 80 ; 9,8 ; 0,20^{\circ} ; \mathrm{m}_{\mathrm{g}}$ $1.660 ; 5,0.0397 \mathrm{~m}$ (1.5625 in.); operating cond tions: $n_{p}, 2000$ rpmi $T_{p}, 271 \mathrm{~N}-m(2400$, in, $-1 b f)$; 10, $0.05 \mathrm{~N}^{\prime} \mathrm{sec} / \mathrm{m}^{2}\left(7.25 \times 10^{-6}\right.$ bf $\left.\mathrm{sec} / \mathrm{in}^{2}\right)$; VB, $0.60 \mathrm{~cm} / \mathrm{sec}\left(6.459 \times 10^{-4} \mathrm{ft}^{2} / \mathrm{sec}\right) ; f_{0}$; 2; bcaring data: (medium series, $44.5 \mathrm{~mm}(1.75 \mathrm{ln}$. bore diameter, deep groove ball bearfing) $0_{11} 0.07 \mathrm{~m}$ (2.75 in.); $C_{S}, 17436 \mathrm{~N}(3920 \mathrm{lbf}) ; \mathrm{FST}_{S T}=\mathrm{H} / 2$.

length of path of contact,

$$
\begin{aligned}
\ell_{T} & =c_{8}\left\{\left[\left(D_{p}+2 / s^{p}\right)^{2}-\left(D_{p} \cos \theta\right)^{2}\right]^{1 / 2}\right. \\
& +\left[\left(D_{g}+2 / 9\right)^{2}-\left(D_{g} \cos \theta\right)^{2}\right]^{1 / 2} \\
& \left.-\left(D_{p}+D_{g}\right) \sin \theta\right\}=0.0168 \mathrm{~m}(0.6593 \mathrm{in} \cdot)
\end{aligned}
$$

Average sliding velocity,

$$
\begin{aligned}
V_{S}=0.0262 n_{p}\left(\frac{1+m_{g}}{m_{g}}\right) l_{T} \\
\\
=1.408 \mathrm{~m} / \mathrm{sec}(55.27 \mathrm{in} / \mathrm{sec})
\end{aligned}
$$

Average rolling velocity, 
$\nabla_{T}=0.1047 n_{p}\left[D_{p} \sin \theta-\frac{l_{T}}{7}\left(\frac{m_{9}-1}{m_{9}}\right)\right]$

$=10.50 \mathrm{~m} / \mathrm{sec}(415.9 \mathrm{~m} / \mathrm{sec})$

Average nommal load,

$$
\pi-T_{p} /\left(D_{p} \cos \theta\right)=1892 N(425.7 \mathrm{Ibf})
$$

Friction coefficient,

$$
f=0.0127 \log \left[C_{9} \pi /\left(s_{W_{0}} \nabla_{S} V_{T}^{2}\right)\right]=0.0287
$$

Average sliding power loss,

$$
P_{S}=C_{1} V_{S} / t=0.1529 \mathrm{~kW}(0,2040 \mathrm{np})
$$

Equivalent contact radius,

$$
\begin{array}{r}
R_{e q} \frac{\left[D_{p}(\sin \theta)+k_{T} / 2\right]\left[D_{g}(\sin \theta)-k_{T} / 2\right]}{2\left(D_{\tilde{p}}+D_{\bar{g}} \sin \theta\right.} \\
=0.0171 \mathrm{~m}(0.6726 \mathrm{in.})
\end{array}
$$

Central EHD film thickness,

$$
\begin{aligned}
& \hbar=c_{10}\left(\nabla_{T^{\mu}}\right)^{0.67}(=0.067)_{R_{e q}}^{0.464} \\
&=1.249 \times 10^{-6} \mathrm{~m}\left(4.927 \times 10^{-5} \text { in. }\right)
\end{aligned}
$$

Contact ratio,

$$
C R=C_{11} \log (\pi \cos 0)=1.787
$$

Average rolling power loss,

$$
P_{R}=C_{2} \bar{V}_{T} \bar{T} S C R=0.0840 \mathrm{~kW}(0.1127 \mathrm{hp})
$$

Windage losses,

$$
\begin{aligned}
P_{W, g}=c_{3}(1+ & \left.2.3 g / R_{g}\right)\left(n_{p} / m_{g}\right)^{2.8} q_{g}^{4.6}\left(0.028 u_{0}\right. \\
& \left.+c_{4}\right)^{0.2}=0.0164 \mathrm{~kW}(0.0220 \mathrm{hp})
\end{aligned}
$$

(10)

$$
\begin{aligned}
P_{W, p}=C_{3}(1+ & 2.3 F\left(R_{p}\right) n_{2}^{2 . B_{R}^{4.6}}\left(0.028 \mu_{0}\right. \\
& \left.+c_{4}\right)^{0.2}=0.0084 \mathrm{kH}(0.0112 \mathrm{np})
\end{aligned}
$$

Load dependent bearing torque loss,

$$
\begin{aligned}
M_{L, 9}=0.0009 F_{S T}^{1.55} C_{S}^{-0.55} D_{m} \\
=0.0351 \mathrm{~N}-m(0.3107 \text { in }=1 \mathrm{bf})
\end{aligned}
$$

$M_{L, p}=0.0009 F_{S T}^{1.55} c_{s}^{-0.55} D_{m}$

$$
=0.0351 \mathrm{~N}-\pi 11(0.3107 \text { in- }-16 f)
$$

Viscous bearing torque 10s5,

$N_{V, g}=C_{6} 1.42 \times 10^{-5} f_{0}\left(y_{B} n_{g}\right)^{2 / 3} 0_{m}^{3}$

$$
-0.1079 \mathrm{~N}-\mathrm{m}(1.024 \text { in-l bf })
$$

$M_{y_{p}, p}=c_{6} 1.42 \times 10^{-5} f_{0}\left(v_{g} n_{p}\right)^{2 / 3} p_{n i t}^{3}$

$$
=0.1634 \mathrm{~N}-\mathrm{m}(1.437 \mathrm{in}-1 \mathrm{bf})
$$

Total bearing torque loss,

$M_{g}=M_{L, g}+H_{V, g}=0.1430 \mathrm{~N}-\mathrm{m}(1.335 \mathrm{in}-1 \mathrm{bf})$

$M_{p}=M_{L, p}+M_{V, p}=0.1985 N-m(1.748 \mathrm{in}-1 \mathrm{bf})$

Total bearing power loss,

$P_{B R G}=2 C_{5}\left(M_{g} n_{g}+M_{p} n_{p}\right)=0.1194 \mathrm{~kW}(0.1001 \mathrm{hp})$

Total system power loss,

$$
\begin{aligned}
P_{T O T}=P_{S}+P_{R}+P_{W, g} & +P_{W, p}+P_{B R G} \\
& =0.3811 \mathrm{~kW}(0.3106 \mathrm{hp})
\end{aligned}
$$

Input power,

$$
P_{I N}=T_{p} n_{p}=56.79 \mathrm{~kW}(70.16 \mathrm{hp})
$$




$$
\text { A. (P } \left.\mathrm{P}_{\mathrm{IN}}=\mathrm{P}_{\mathrm{TOT}}\right) / \mathrm{P}_{1 \mathrm{~N}} \times 100=99.34 \%
$$

\section{Comparison with Test Dato}

Figure 3 shows the comparison of this power loss method with the dats of [10] which was generated on a back-to-baek test stand with a spur gearset. In [16] speed, torvue, ofl flow rate, oil jet location, gear width and lubricant viscosity were test variables. The theory of [7] generally shows good agreement with the data, especially for the higher flow rate. The test data of [16] indicates that out of mesh lubrication, that is the oil jet is directed into the outlet of the gear mesh, can reduce the power loss by several hundredths of a kW. The present theory has no terms to account for this reduction.

Included in Fig. 3 for comparison is the theorem tical prediction of [6]. The somewhat higher predicted loss from this theory is thought to be primarily due to the choice of friction coefficient expression which tends to overestimate the actual coefficient of friction.

\section{DISCUSSION OF RESULTS}

The theory of [7] was used to deternine the effects of various gear geometry and operating conditions on gearset afficiency. The results are shown in Figs. 4 to 10. Gearset efficiencies shown in these figures do not inelude the effects of bearing loss.

\section{Effect of Gear Load}

The effect of torque on gearset efficiency is shown in Fig. 4 for gears of three pitch diameters. The general trends shown here are typical for the wide range of gear geometries and operating conditions that were considered. At very low torque values efficiency is low due to the tare losses but efficiency rises rapidly with small increases in torque. At higher torque levels gear efficiency is relatively insensitive to torque, being genexally greater than 98 percent at torque values which exceed 5 percent of the torque occurring at maximum efficiency.

The effect of pitch dianeter at low torque levels is significant. Here a smaller gear is much more efficient than a large gear. At higher torque levels the differences are much less.

In Fig. I this data is replotted against a gear capacity factor, $K$, described in [17]:

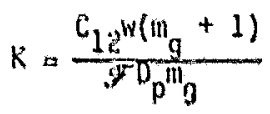

where

$C_{12}=1.45 \times 10^{-4}$ (SI units) $C_{12}=1.0$ (English units) The allowable K-factors for helical and spur gears, tabularized in [17], generally range from a value of about 100 for low hardness-generati steel-gears to about 1000 for aircraft quality, case hardened and ground, high-speed gearing. A nominal K-rating for a generai-purpose industrial drive, with $300 \mathrm{BHN}$ s',eel gears, carrying a uniform load at a pitch-line-yelocity of $15 \mathrm{~m} / \mathrm{sec}(3000 \mathrm{fpm})$ or less would typically range from 275 to 375 . The K-factor tends to nomalize the efficiency data of Fig. 4. Like Fig. 4, Fig. 5 shows that larger gears generally have superior peak efficiency. However, where Fig. 4 showed that at equal, low torque levels smaller gears are more eff i- ctent, in Fig. 5 the reverse is true at equal, low K-factors. This is because at equal K-factors the large gearset is operating at a significantly higher torque level (where the efficiency is greatly improved) than the smaller gearset.

Also, pitch-line-velocity is used here instead of rotational speed for its nomalizing effect. Pitchline-velocity neduees rotat lonal speed for large: diameter gears so that a more realistic comparison can be made anong different sized gearsets.

\section{Effect of Diametral Pitch, Pinion Pitch Diameter, Pitch-Line-Velocity and Ratio}

The "carpet" plots in Figs. 6 to 9 show the simultaneous effects of three variables: diametral pitch, pitch diameter and pitch-line-velocity, on gearset efficiency (exeluding support bearing losses). These varyables and gear load were found to have a greater effect on efficiency than ratio or face width. Two loading situations were chosen; (a) light load, $K=10$ and (b) muderate to heavy load, $K=300$, close to the maximum efficiency of the gearset as shown in Fig. 4. The magnitude and trends of efficiency results at $K$ a 1000 are quite sirilar to those at $k=300$ and are not shown here.

In Fig. 6 , the $k$-f actor is constant at 300 and the ratio equais ene. In this and succeeding carpet plots, the three key variables are represented along orthogonal, intersecting planes. Three values for each of the three variables are presented. The efficiensy at any combination of these values occurs at an intersection point. Thus, efficiency at intermediate values can readily be found by interpolation between

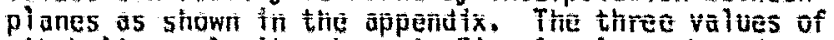
pitch-line-velocity shown in Fig. 6 , along shaded planes, are $1.3,5.1$ and $20.3 \mathrm{~m} / \mathrm{sec}(250,1000$ and $4000 \mathrm{ft} / \mathrm{min})$. Pitch diameter varies along one set of planes from 1.6 to $6.3 \mathrm{~cm}$ ( 9 to $6 \mathrm{in}$.) and diametral pitch varies from 4 to 16 along the other.

The most efficient combination of pinion pitch di ameter and diametral pitch is the largest diameter gear having the finest-pitched teeth. Conversely the least efficient gearset is the smallest diameter gear having the coarsest pitch. At this $K$-factor value, an increase in pitch-line-velecity tends to increase of ficiency, particularly for small, coarse-pitched gears. Although not shown, efficiency continues to increase at speeds to $40.6 \mathrm{~m} / \mathrm{sec}(8000 \mathrm{ft} / \mathrm{min})$ but at a much slower rate. The max inum increase in eff iciency, was U.21 percentage points at a pinion diameter of $1.6 \mathrm{~cm}(\mathrm{q} \mathrm{in.})$ and aiametral pitch of four.

Diametral pitch had the greatest effect on efficiency for any speed and gear size. At a constant diametral pitch value of 16 , ehanges in piteh diameter and pitch-line-velocity had little effect. However, at a diamet al pitch of 4 , both these paranaters had large effects. The nigher efficiencies feund with the fine $p$ itched gears are primarily due to lower sliding velocities and, therefore, reduced power losses.

As shown in Figs. 4 and 5 , large diameter gears tend to have superior perfomance. At a constant. pitch-line-velocity the rotational speed decreases is the diameter increases. This causes a reduction in the sliding velocity which in turn limits the sliding power loss. Thus the increase in efficiency shown as diameter increases is due to a reduction in magnitude of sliuing veloeity.

Also showt in Figs. 4 and 5 is that an increase in pitch-i ine-velocity results in an increase in efficiency. As pitch-line-velocity is increased botil the sliding and rolling velocities increase. In Eq. (1i) it can be seen that an increase in either of these 
veloeitles will reduce the coefficlent of friction. This reduction in friction coefticient tends to reduce the slicing power loss so that the sliding loss does not increase directly with pitch-line-velocity as does the input pewer. The net rosult is that the efficiency is improved.

In Fig, 7 the results of changing gear reduction ratio from one to six at $K-300$ are shown. Since pinion diameter is held constant a change in ratio means a change in gear diameter. A comparison of Figs, 6 and 7 reveals that ratio has a negligible effect on efficiency at pitcholine-velocity of 20.3 $\mathrm{m} / \mathrm{sec}(4000 \mathrm{ft} / \mathrm{min})$ and a small effect at lower $\mathrm{pitch}$ line-velocitics. At low speeds the efficiency of small, coamsempitckied gears are most improved by an increase in atio. A maximum increase in efficiency was found to be approximately 0.5 percentage points for a change in ratio of one to six. The reason for lower losses at the higher ratios is tye to a slight reduction in sliding velnctiles. Howver, overali the effect of ratio on efficiency was jutiged to be slight. In $\mathrm{F} / \mathrm{g}, 8$ the $\mathrm{K}$-factor has been reduced to 10 and ratio is still equal to one. This is essentially an. unloaded gearset and the losses are almost ent irely the tare losses - the rolling and windage losses. Gear tooth sliding losses are insignificant since the tooth looding is very low. The effect of the variables at $K=10$ are significantly different than a's $K$ 300. The effect of pitch-line-velocity is reversed. The most efficient piteh-line-velocity is the lowest value and a significant reduction in efficiency occurs as pitch-line-velocity increases. This is due to the fact that the tare losses are a strong function of rotational speed. The efficlencies are much lower since the poiner being trañomftted is very iow.

The effect of increased effiriency with increased dfameter remains the yame here at the lightly loaded case. The effect of diametral pitch on efficiency is greatly reduced at this low K-factor. Only at the lowest pitch-line-velocity, where sliding losses are still significant, $1.3 \mathrm{~m} / \mathrm{sec}(250 \mathrm{ft} / \mathrm{min})$, will the efficiency still increase appreciably with finer pitched gear teeth. At higher pitch-line-veloc ities where the silding loss becomes insign if icant relative to the rolling loss, the diametral pitch nas virtually no effect on efficiency. Efficiency data calculated at $5.1 \mathrm{~m} / \mathrm{sec}$ ( $1000 \mathrm{ft} / \mathrm{min}$ ) were intentionaliy omitted in $\mathrm{F} 9 \mathrm{~g} .8$ for clarity since these data were within 0.5 percentage points of the data at $1.3 \mathrm{~m} / \mathrm{sec}(250$ $\mathrm{ft} / \mathrm{min}$.

In $\mathrm{Fig}$. 9 the gear ratio was increased to six at $K$ 10. As mentioned previously, this is equivalent to increasing the gaar diameter by a factor of $s i x$. At $1.3 \mathrm{~m} / \mathrm{sec}(250 \mathrm{ft} / \mathrm{min})$ ratio has little effect on efficiency. However, at $20.3 \mathrm{~m} / \mathrm{sec}(4000 \mathrm{ft} / \mathrm{min})$ the increased rat io causes an approximate 0.5 percentage point drop in effic lency while at $40.6 \mathrm{~m} / \mathrm{sec}(8000$ $\mathrm{ft} / \mathrm{min}$ ) efficiency is substantially reduced by about 4 percentage points. Thus ratio has its strongest effect at high pitsh-line-velocity and light loads where rolling and windage losses are the main source of power ioss.

\section{Effect of Face Widl. $/ 0$ iameter Ratio}

In the previous carpet plots, the $\mathscr{F} / 0$ ratio was held constant at 0.5 . In Fig. 10 the effect of $\$ 10$ ratio on efficiency at severai values of piteh-linevelocity and $K$-factors is shown. In most cases the efficiency change is very smal1, less than 0.2 per-

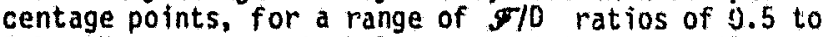
2.0. However, at pitch-line-velocities above 20.3 $\mathrm{m} / \mathrm{sec}(4000 \mathrm{ft} / \mathrm{min})$ at a low $k m$ factor of 10 , the var- lation in efriciency with $\$ 70$ ratio is sonewhat more significant primarily due to the effects of windage. The maximum variation occurs at $40.6 \mathrm{~m} / \mathrm{sec}(8000$ $\mathrm{ft} / \mathrm{min}\rangle$ where the narrowest gearset $(\$ 70-0.5)$ is less efficient than the widest gearset by 4,1 percentage points. However, for a wide range of operating. conditions the $\$ 70$ ratio does not significantly af fect efficiency.

\section{Breakdown of Gear System Loss}

A theoretical breakdown of the various components of gear system power loss for the test gears of [16] is shown in Fig. 11. At low pinion speeds (Fig. il(a)), the sliding loss accounts for most of the sysm tem losses. However, at higher speeds (Figs. 11(b) and (c)), the pinion bearing losses become increasingly more important. At a pinion speed of $2000 \mathrm{rpm}$, the gear and pinion windage losses, which are of ten neglected, contribute as much as 10 percent of the total power loss and should not be ignored.

At low torque levels, the sliding loss is low since this loss is a direct function of load. The rolling loss is relatively insensitive to torque, being proportional to $\mathrm{f} 1 \mathrm{~lm}$ thickness, so it is a major source of power loss at low torques, particularly at the higher speeds.

Figure $11(\mathrm{c})$ clearly illustrates the potential pitfall of disregarding the speed dependent losses when computing gearbox losses, which is all too of ten the case. Even at the full load value of $271 \mathrm{~N}-1 \mathrm{~m}(200$ $f t / l b f)$ where the sliding losses are a maxmimum, they still represent about one-half of the total gear mesh losses which excludes bearing losses. It is also instructive to nute that at this operating condition, the total support bearing losses are naarly 80 percent as large as the gear sliding losses. Good estimates of gear rolling and windage losses along with support bearing losses are vital to accurately determining the power consumption of the gearbox.

Finally, Fig. 11 illustrates that the unloaded or tare losses associated with a gearset can be a surprisingly high pencentage of the loaded power losses. of course methods which use just a sliding coefficient of friction to predict losses will completely miss this tare loss since without load there can be no sliding power loss. This is why these methods significantly overestimate part-load efficiency.

In Fig. 12 this tare or unloaded power loss is plotted as a percentage of full load loss over a wide range of pitch-line-velocities and gear sizes fer the gearset studied in Figs. 4 and 5 . This tare loss is comprised entirely of rolling, windage and support bearing power loss. The support bearings were scaled in proportion to the gear size as shown.

From Fig. 12, it is apparent that pitch-line-velocity has a more dominant effect than diameter on percent tare loss, since at equal pitch-line-velocity the large gearset is actually turning slower. Over the range of operating conditions considered, tare losses are appreciable and should not be overlooked when deternining required cooling capacity or idling power consumption.

\section{SLMMARY}

A method to calculate gear inesh power losses from the conditions occurring at one point along the path of contact was developed. The sliding and rolling velocities occurring at this point can be used to conipute the average sliding and rolling-traction power losses for the mesh. In addition, expressions are given to determine gear windage and support bearing 
losses. This approximate method was compared to the more exact numerical method of [7]. A design example was given to lllustrate the application of the nethou developed. The analys is presentell was used to generate efficiency glots at low and moderate to high loads which showed which gear geometries and operating val' lables lead to the highest jearset efficiencies. The following results were obiairicd from this investigation:

1. The single point, approximate gear loss method gave efficiency results within 0.1 percentage points of the full numerical integration solution of [7]. The only exception occurs at light load and high speeds $(A 0 \mathrm{~m} / \mathrm{sec})$ where the lack of a thermal correction factor to limit EHO film thickness causes the deviation to increase to 1 percentage point.

2. Under moderately-to-heavily loaded conditions (K-factor, 300$)$, an increase in diametral pitch. pitch diameter and pitch-line-velocity causes an increase in gearset efficiency. However, uncer light loads $(K-f a c t o r=10)$, an increase in pitch-line-ve)ocity causes an efficiency loss and an inerease in dianetral pitch has only a slight benefit on gear efficiency primarily at low velocities.

3. Gear ratio and face widthisto-diameter ratio generally had minor effects on efficiency except at light loads where high ratio and narrow gearsets tend to be less efficlent, particularly at high pitch-linem velocities (above $20 \mathrm{~m} / \mathrm{sec}$ ).

4. Rolling-traction power losses, support bearing power loss and windage losses, to a lesser extent, were significant portions of the total gear systein loss. Unloaded or tare gear power losses at operating cpeed can be as inuch as 65 percent of the loaded, maximull power loss.

\section{APPENDIX}

To determine the efficiency of a gearset not 10cated along the axes appearing on a carpet plot. a three dimensional interpolation must be done. Since the value of the three independent veriables are uni.. formly spaced along the carpect plot axes a linear interpolation is all that is required. An example of such an interpolation is shown in Fin. 13 where Fig. 9 is interpolated for a pinion diameter of $2.8 \mathrm{~cm}(7$ in.) dtametral pitch of 10 and a pitch-line-velocity of $30 \mathrm{~m} / \mathrm{sec}(6000 \mathrm{ft} / \mathrm{min})$. First, planes of constant pinioi dianeter, diametral pitch and pitch-line-veloeity equal to the required values are established by inear interpolation jiong the boundaries where values are given. As these planes are established, intersection lines between planes will form leading to one intersection point. This point establishes the required gearset efficiency by projection to the eff it ciency scale. In this case, the required gearset efficiency is determined to be 94.3 percent.

\section{REFERENCES}

1. Anderson, N. E., and Loewenthal, S. H., "Effect of Geonetry and Operating Conditions on Spur Gear System Power Loss," ASME paper no. 82-62/DET-394 Sept. 1980.

2. Shipley, Eugene E., "Loaded Gears in Action," Gear Handbook, Ist, ed, D. W. Dudley, ed. McGrauiit, Wew York, 1962, ch, 14, pp, 14-1-14-6u,

3. Buckingham, Earle, "Eff iciencies of Gears," Analytical Mechanics of Gears, Dover, New York, 1963, ch. 19, Pp. 395-425.

4. Mearitt, H. E., "Efficiency and Testing," Gear Engliaering, Wiley, New York, 1972, ch. $22, \mathrm{pp}$. 345-35T.

5. Martin, K, $F$, "A Review of Friction Predictions in Gear "eeth," Wear, Vol. 49, No, 2, Aug, 1978, pp. $201-238$.

6. Chiu, $Y . P$., "Approx imate Calculation of Power Loss in Involute Gears," ASHE Paper 75-PTG-z. 0et. 1975.

7. Anderson, N. E. and Loewonthal, S, H., "jpur-Gear. System Efficiency at Part and Full LOad," NASA TP 1622 , AVRAOCOH TR 79-46, 1980.

8. Mann, R. W., and Marston, C. H., "Friction Drag on Blated Discs in Housings, " Journal of Baste Engineering, Vol. 83, No, 4, Dec. 1961, pp. $719=723$.

9. Daily, J, W., and Nece, R. E., "Chamber Dimension Effects on Inuced Flow and Frictiona Resistance of Enclosed Rotating Disks," Journal of Basic Engincering, Vol. 82, No. 1, Mar, 1960, pp. $217=23 \%$.

10. Harris, T, A., Rolling Bearing Analysis, Wiley, New York, Iyou,

11. Benedict, G. H. and Relley, B. Wr, "Instantaneous Coefficients of Gear Tooth Friction," ASLE Transactions, Vol. 4, No. 1, Apr. 1961, pp. 59-70.

12. Crook, $A$, W." "The Lubrication of Rollers. IV. Measurements of Friction and Effective Viscose ity," Philosophical Transactions or' the Roya? Society (London, ser. $A$, VoT. 255, Wo. 1050, Jan, 17, 1963, pp. 281-Jis.

13. Hamrock, B, J. and Dowson, D.; "I sothermal Elastohydrodynamic Lubrication of Point Contacts. III - Fuliy Flooded Results," Journal of Lubrication Technology, Vo 1. 99, No. a, Apr. 1977, pp. $264=276$.

14. Cheng, H. S., "Prediction of Filin Thiekness and Sliding Frictiona coefficient in Elastolydrodynamic Contacts," ASME Design Enaineering Technology Conference, 1st. ASME, New York, 1974, pp. $285-293$.

15. Bowen, C. II., Braddock, C. E., and Walker, R. D. "Instalistion of a High-Reduction-Ratio Transmission in the Uit-1 Helicopter," BHR-299-099-112, Bell Helicopter Co., Fort Horth, Texas, 1969 (USAIILABS-TR-60-57, A0-855747).

16. Fletcher, H. A. G., and Bamborough, J., "Effect of oil Viscosity and Supply Conditions on Efficiency of Spur Gearing," NEL-138, National Engineering Laboratory, Glasgow, Scotiand, 1964.

17. Wellawer, E, J., "Lcad Rating of Gears," Gear Handhook, McGraw-Hill, New York, Ist. ed., I962, D. W. lüdles, ed., ch 13, pp. 13-1 - 13-48. 

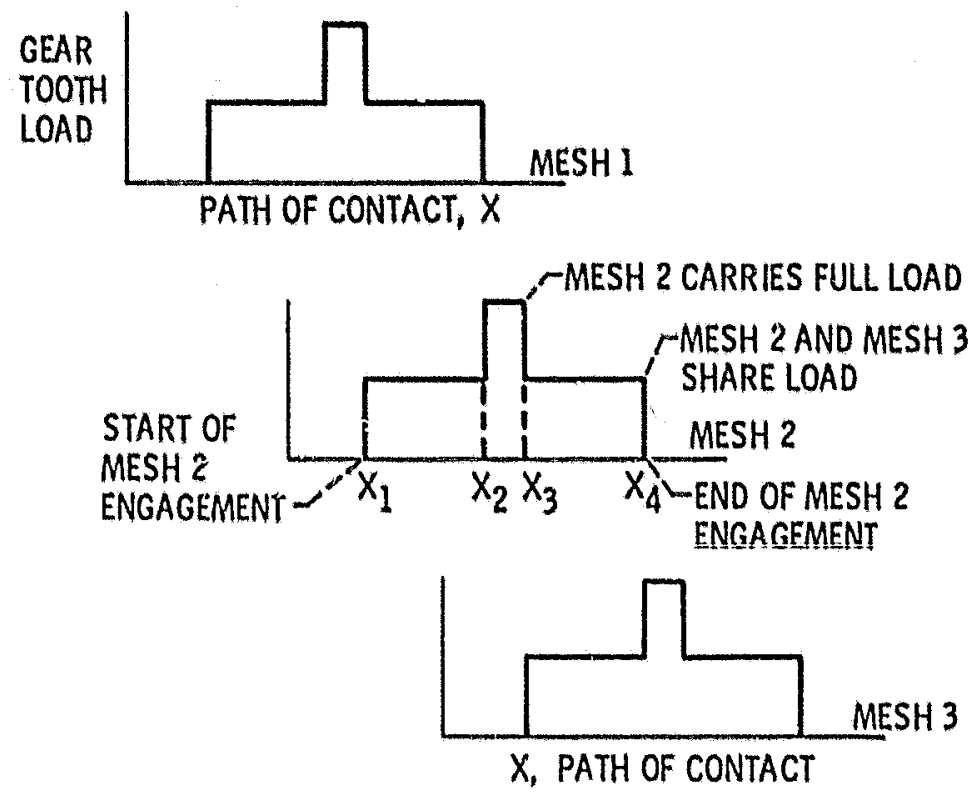

Figure 1, - Tooth load sharing diagram. 


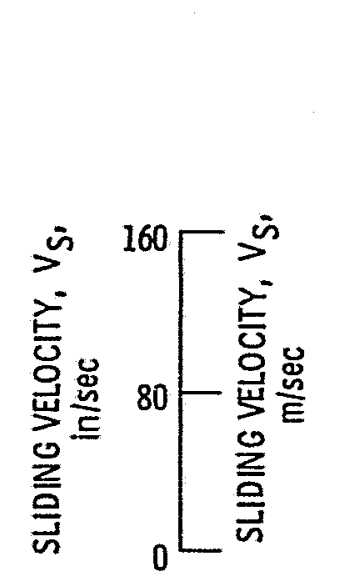

AVERAGE VELOCITY AT

EVALUATION POINT FOR

SIMPLIFIED EXPRESSION 7
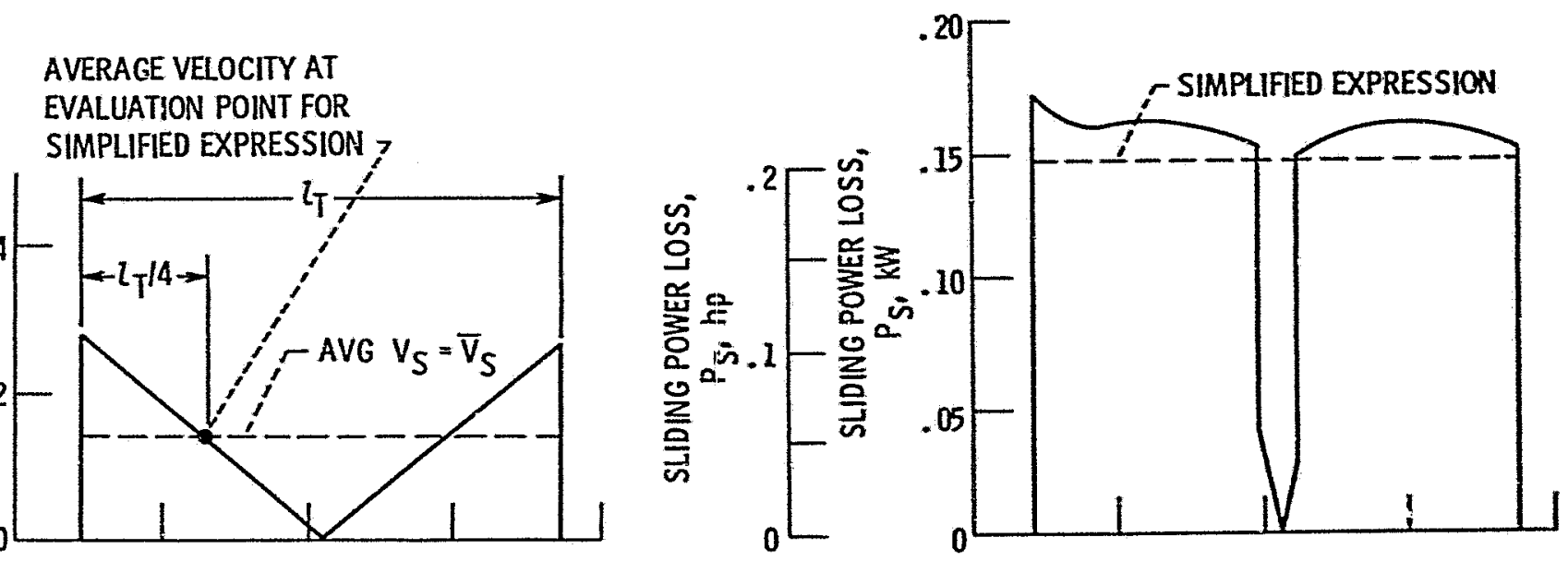

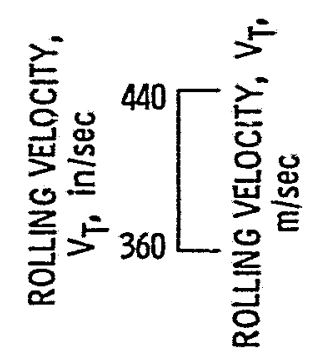
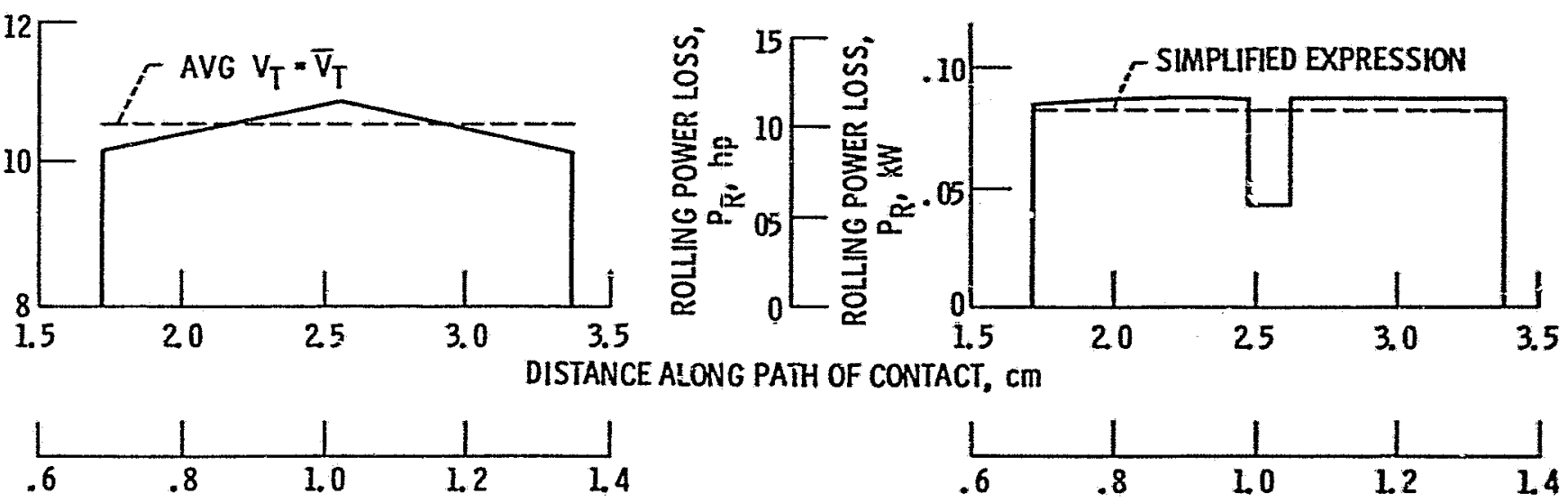

DISTANCE ALONG FATH OF CONTACT, in.

Figure 2 - Instantaneous and average values of sliding velocity, rolling velocity, sliding power loss and rolling power loss across the path of contact of test gears from [16]. Pinion speed, $2000 \mathrm{rpm}$; pinion torque, $271 \mathrm{~N}-\mathrm{m}(200 \mathrm{ff}-1 \mathrm{bf})$; pinion pitch diameter, $15.2 \mathrm{~cm}(6 \mathrm{in}$.); ratio, 167; diametral pitch, 8; pressure angle, 20\%; pinion width/diameter ratio, 0.26; lubricant visos,ity, $60 \mathrm{cs}$. 

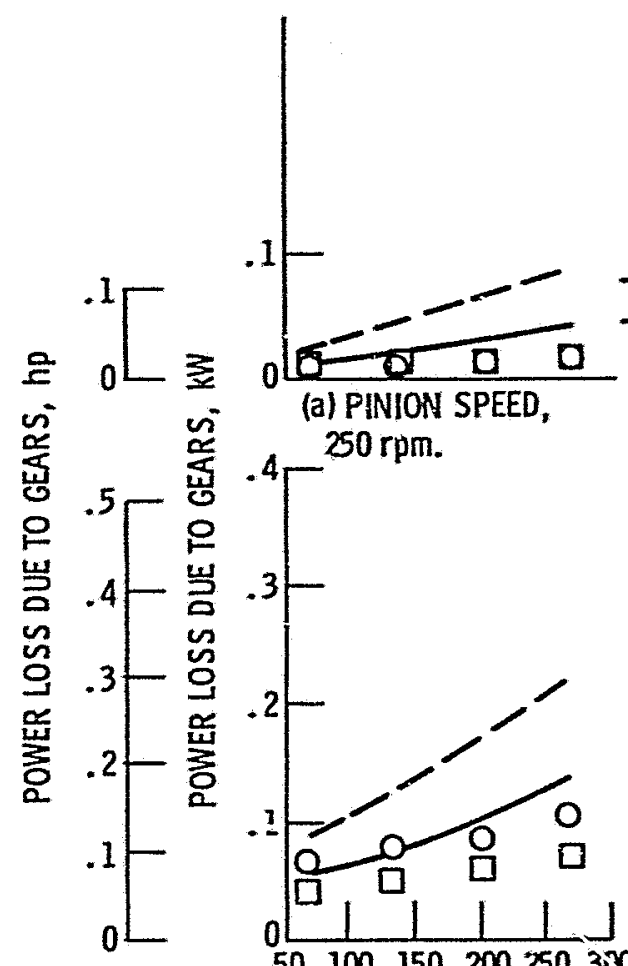

\section{N.E.L. DATA [16]}

OIL FLOW RATE,

I/min (gal/min

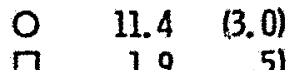

$\begin{array}{lll}0 & 1.9 & .51\end{array}$

- THEORY OF CHIU[6] THEORY OF ANDERSON AND LOEWENTHAL $250 \mathrm{rpm}$.
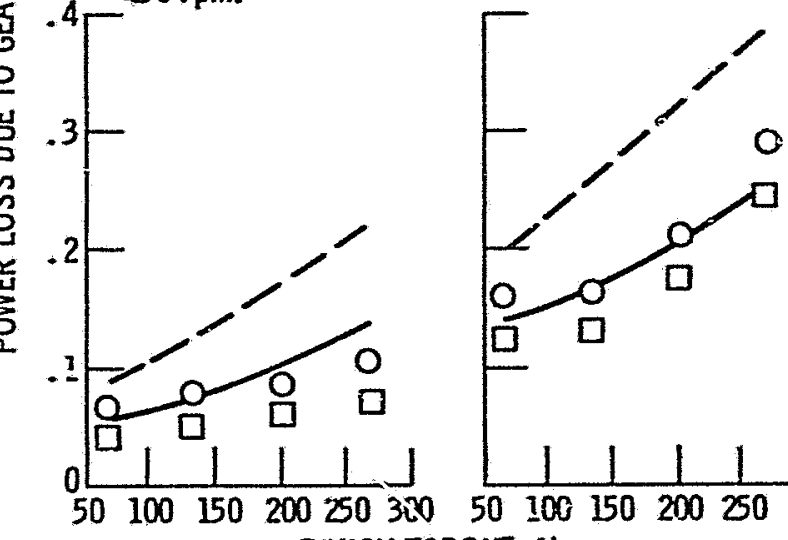

\section{PNION TORQUE, N-m}
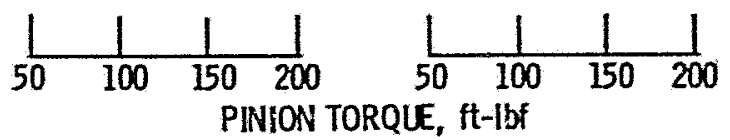
(b) PINION SPEED,
(c) PINION SPEED, $1000 \mathrm{rpm}$.
$2000 \mathrm{rpm}$.

Figure 3. - Comparison of prest:cted gear power loss for into mesh lubrication with data of [iü]. Pinion pitch diameter, $15.2 \mathrm{~cm}$ ( 6 in. ); ratio, 1.67; diametral pitch, 8 ; pressure angle, $20^{\circ}$; pinion width/diameter ratio, 0.26; lubricant viscosity, 60 cs.

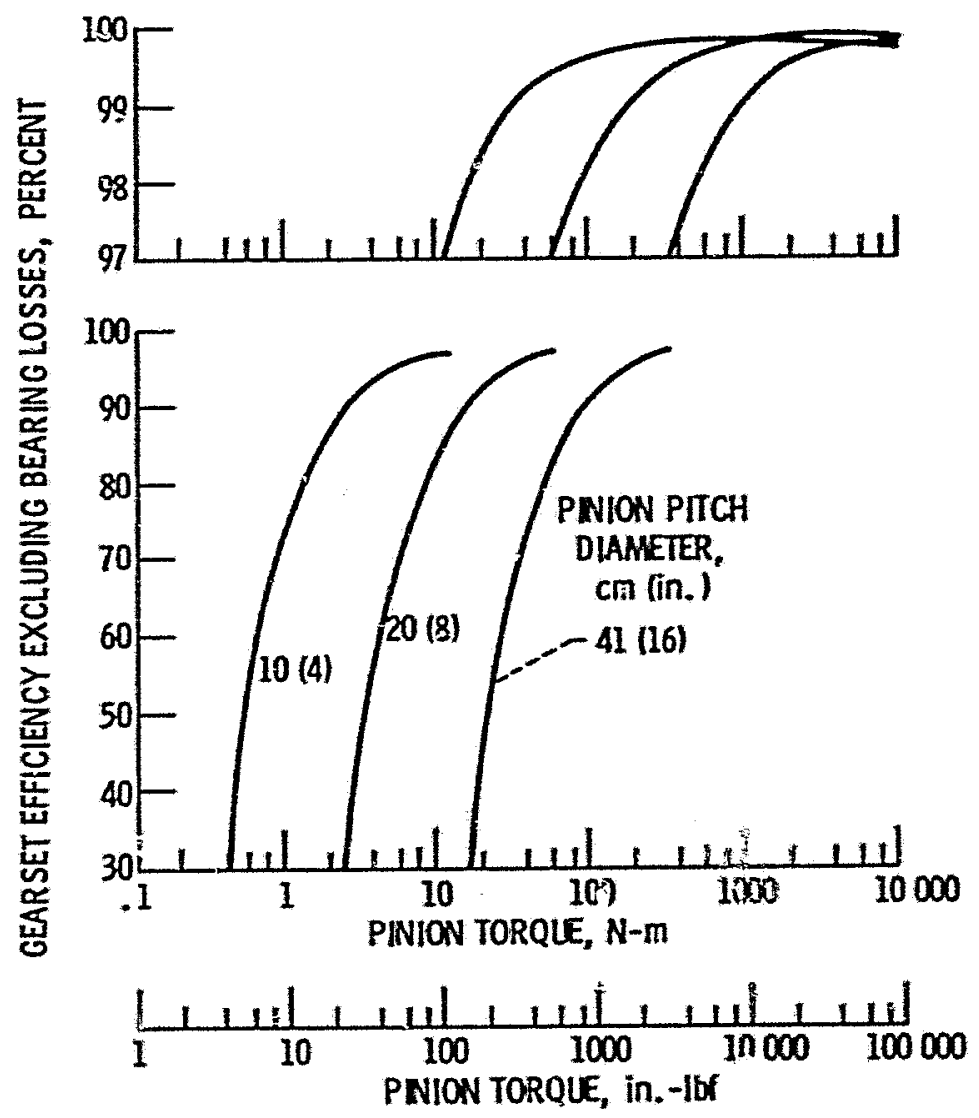

Figure 4. - Effect of torque on gearset efficiency for three pitch diameter pinions. Pitch line velocity, $20,3 \mathrm{~m} / \mathrm{sec}$ (4000 ft/min); ratio, 1. 0, diametral pitch, 32, pressure angle, $20^{\circ}$; pinion widthldianeter ratio, 0.5; lubricant viscosity, $30 \mathrm{cp}$. 


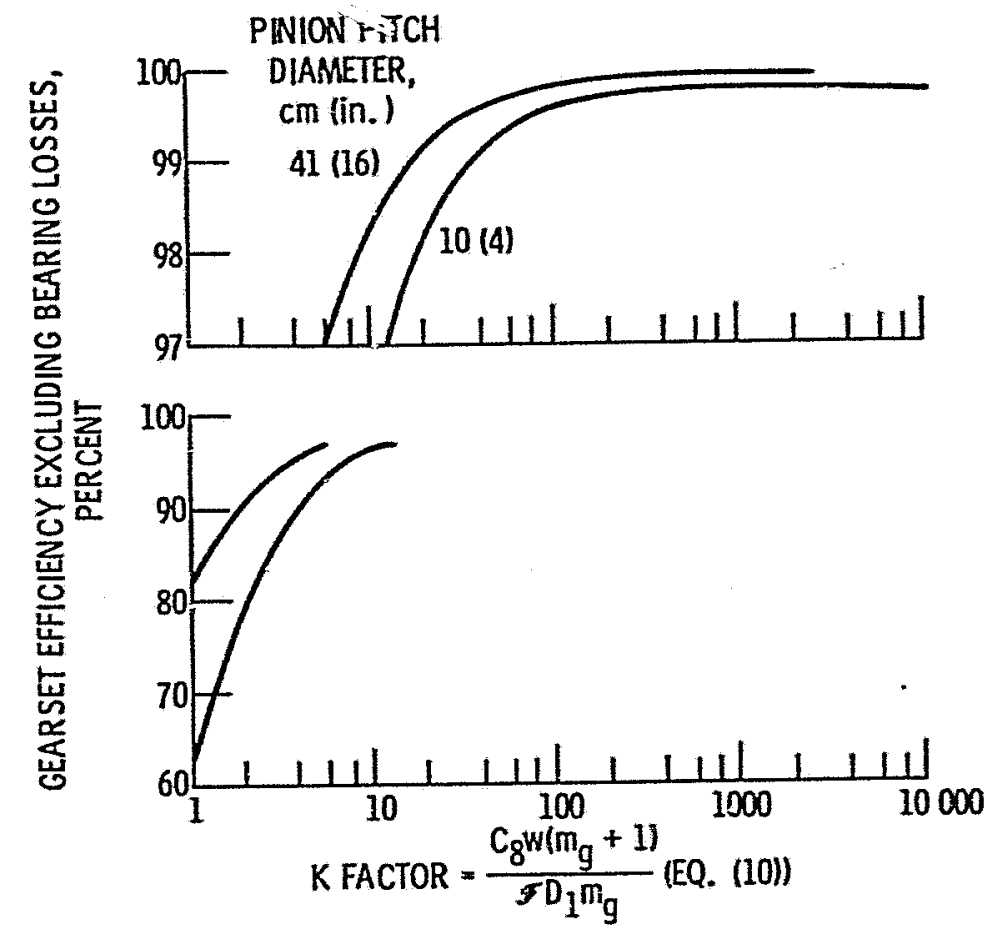

Figure 5. - Effect of pitch fiameter on gearset efficiency as a function of $K$ factor. Pitch line velocity, $23.3 \mathrm{~m} / \mathrm{sec}$ (4000 ft/min); ratio, 1.0; diametral pitch, 32; pressure angle, 20 ; pinion width/diameter ratio, 0.5 ; lubricant viscosity, $30 \mathrm{cp}$.

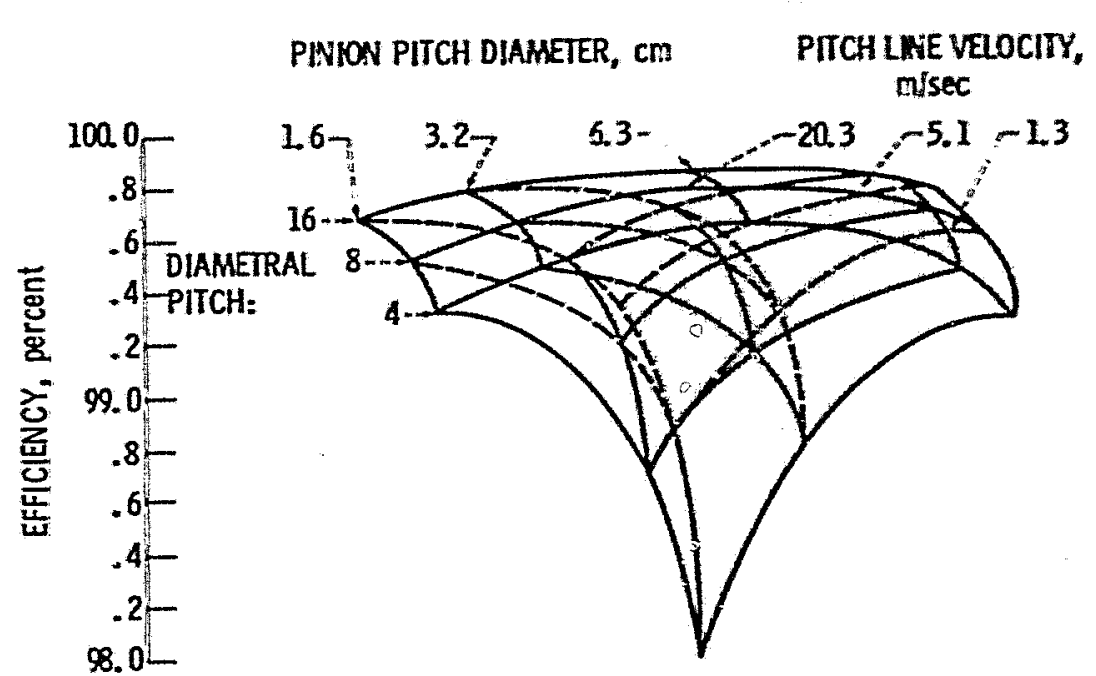

Figure 6. - Effect of pinion diameter, diametral pitch and pitch line velocity on gearset efficiency at a K-factor of 300; ratio, 1.0 , pressure angle, $20^{\circ}$; pinion width/diameter iatio, 0.5; fubricant viscosity, $30 \mathrm{cp}$. 


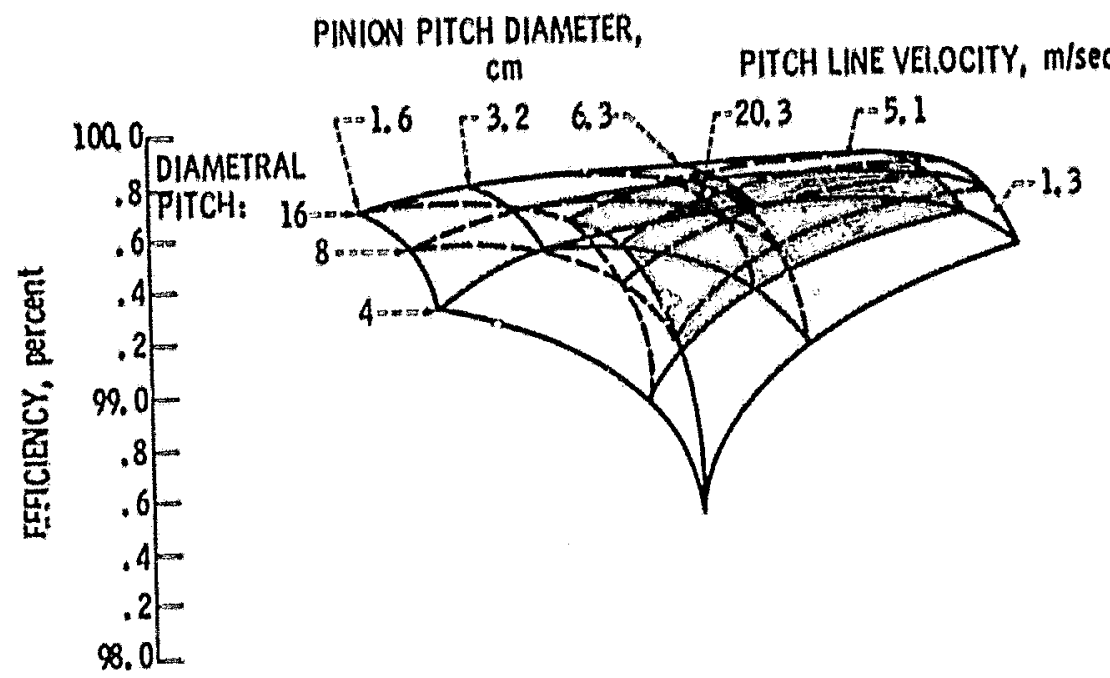

Figure 7. - Effect of pinlon diameler, diametral pilch and pltch line velocity on gearset efflclency at a K-factor of 300; ratio, 6; pressure angle, 200; pinion width/diameter ratio, 0.5 ; lubricant viscosily, $30 \mathrm{cp}$.

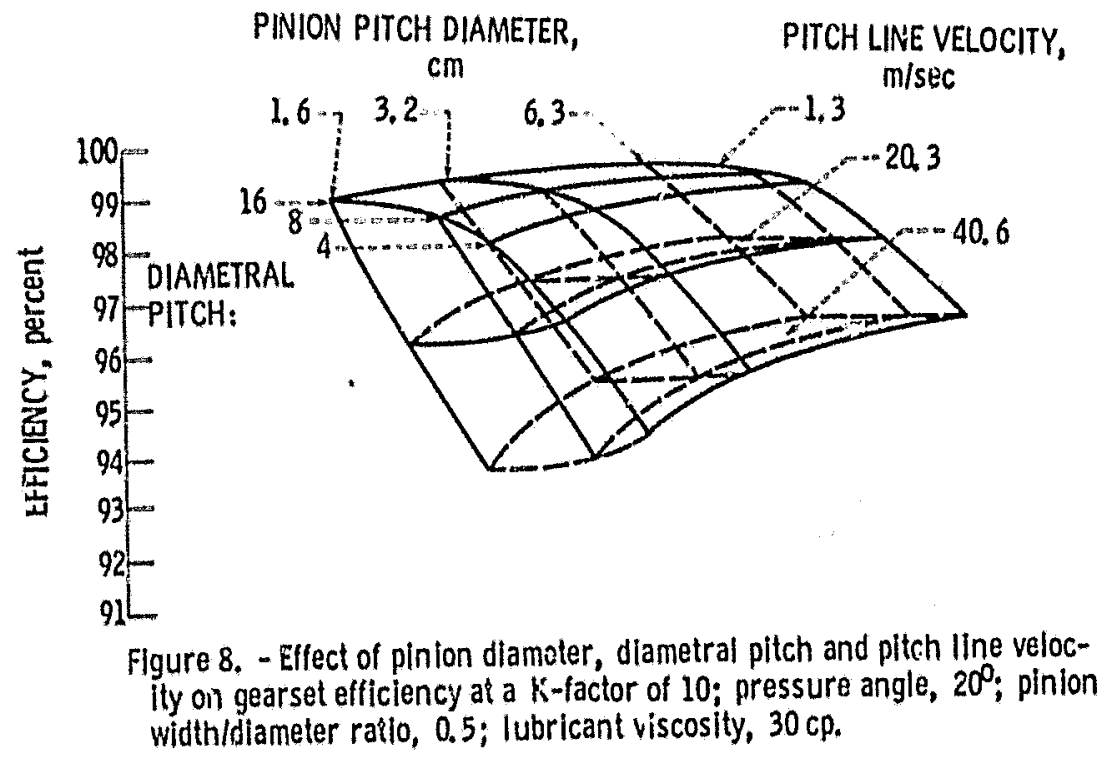




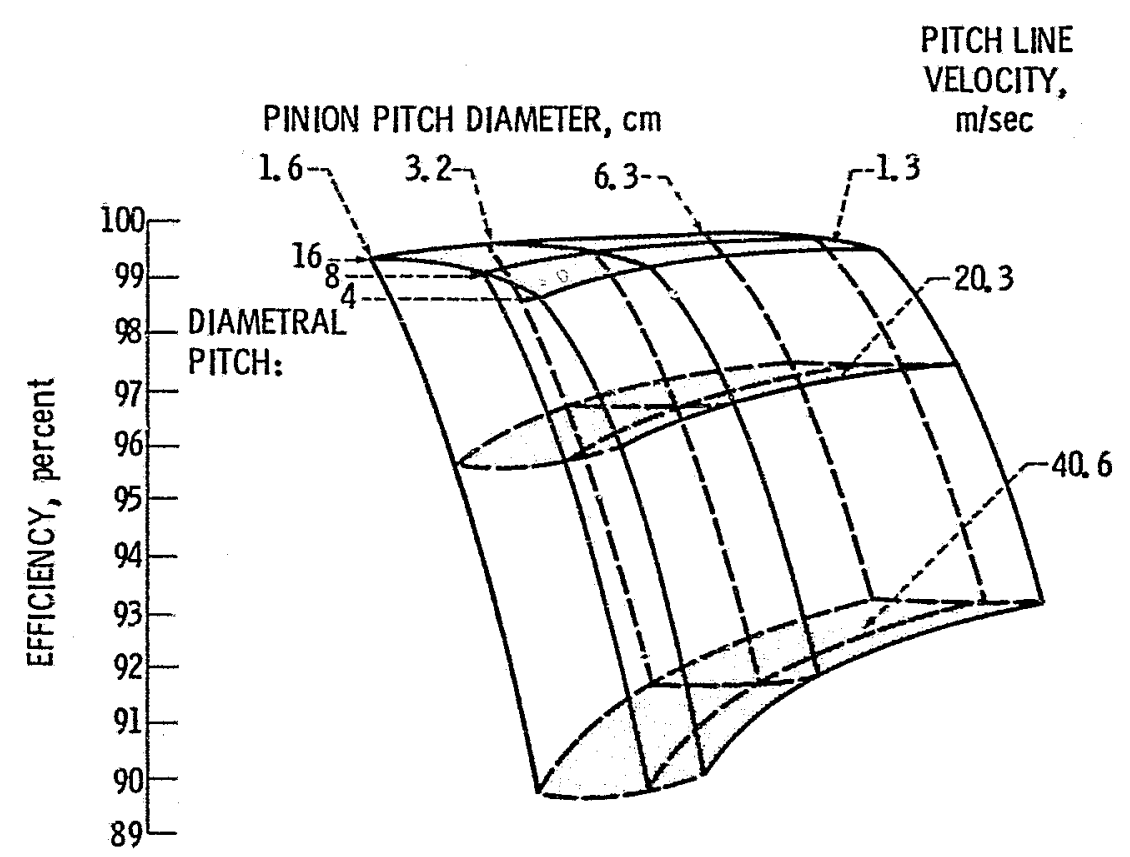

Figure 9. - Effect of pinion diameter, dametral pitch and pitch line velocity on gearset efficiency at a K-factor of 10 ; ratio, 6 ; pressure angle, 20; pinion width/diameter ratio, 0.5; lubricant viscosity, $30 \mathrm{cp}$.

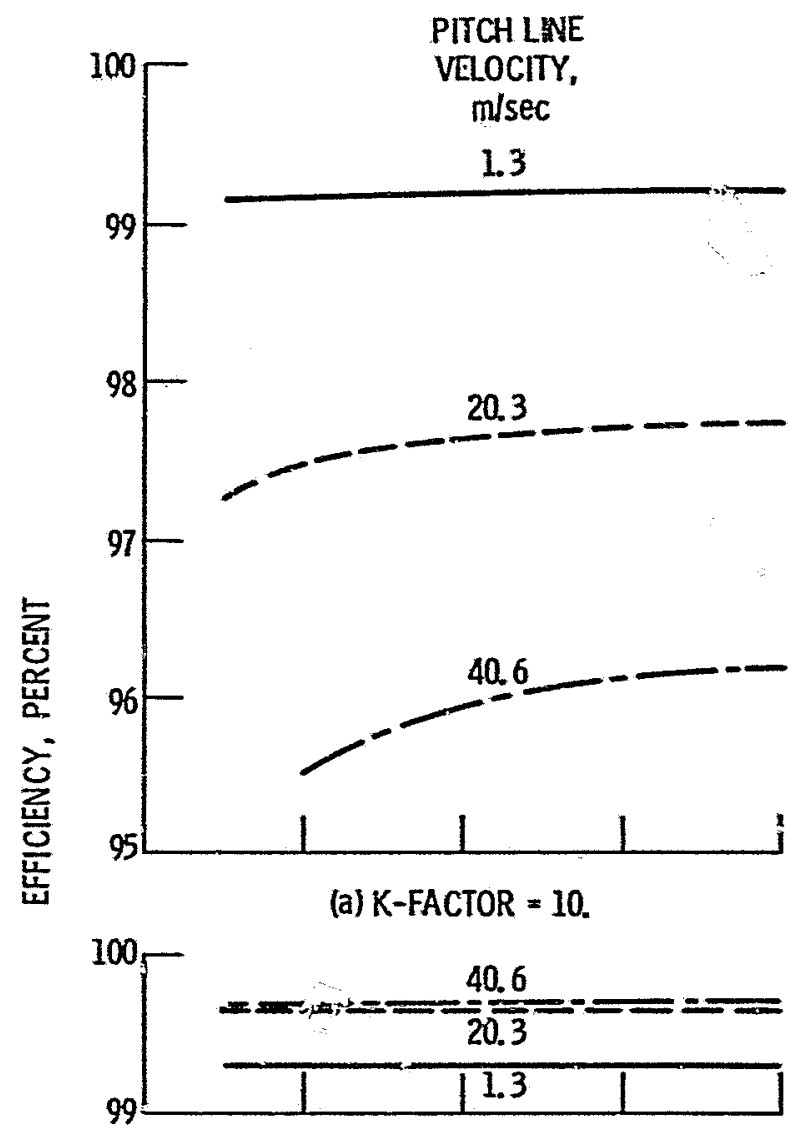

(b) $K-F A C T O R=300$.

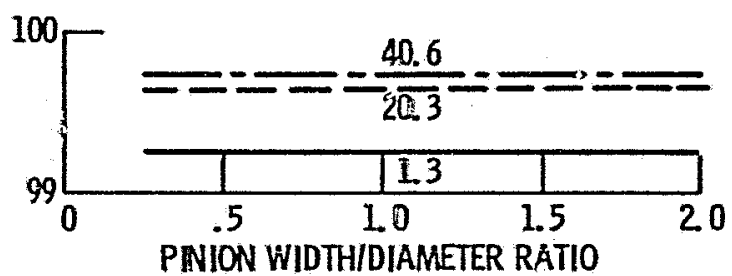

(c) $K-$ FACTOR $=1000$.

Figure 10. - Effect of pinion widthldiameter ratio on gearset efficiency at various $\mathrm{K}$-factors (gear lnads). Pinion pitch diameter $=3.2 \mathrm{~cm}(8 \mathrm{in}$.$) ;$ ratio, 1.0, diametral pitch, 8; pressure angle, $20^{\circ}$; lubricant viscosity, $30 \mathrm{cp}$. 


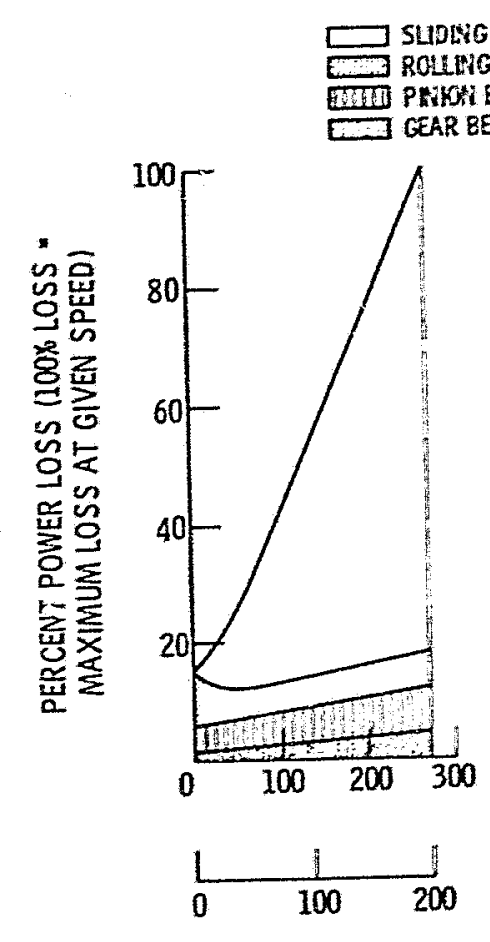

(a) PINION SPEED, $250 \mathrm{rpm}$.
Z2D GEAP FHEDAGE

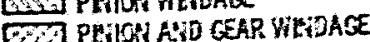

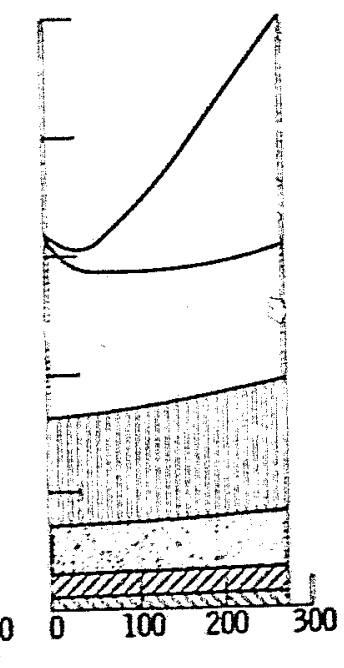

PINION TORQUE, N-M

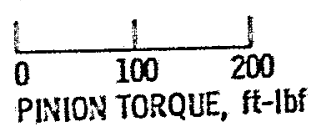

(b) PNION SPEED,

$1000 \mathrm{rgm}$.

( Co components. Pinion itch diameter, $15.2 \mathrm{~cm} 16$ in. 5 ratio, 1.67; diameiral pitch, 8 ; pitch diamer,

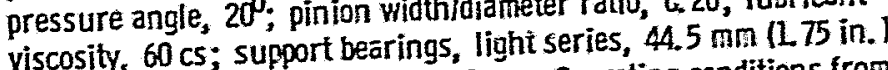
bore diameter deep-groove ball bearings. Operating conditions from figure 3.

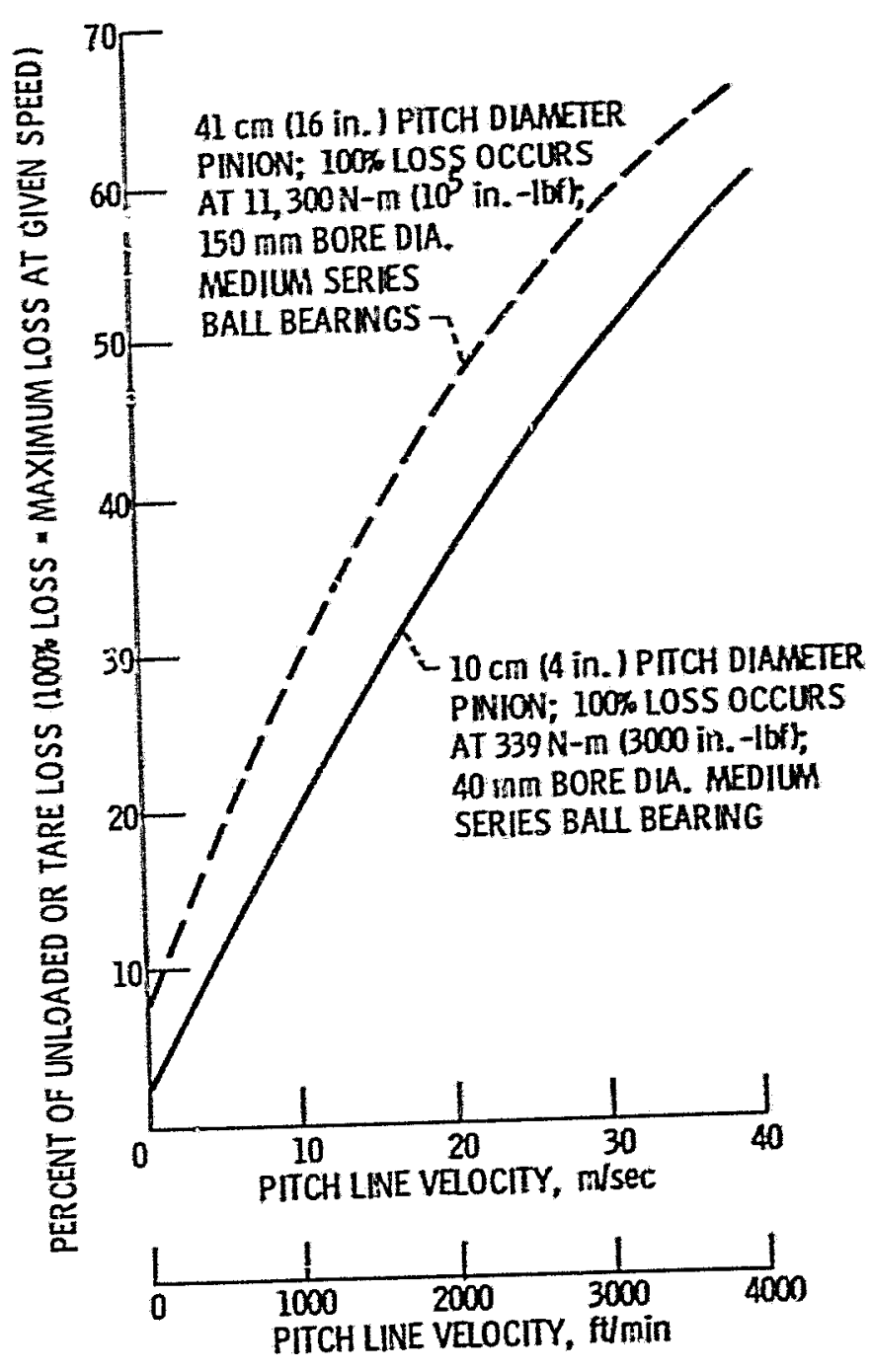

Figure 12. - Percent tare loss as a function of pitch line veiocity and pitch diameter. Ratio. 1. 0 , diametral pitch, 8; pressure angle, $20^{\circ}$; pinion width/diameter ratio, 0.5 ; lubricant viscosity, $30 \mathrm{cp}$. 


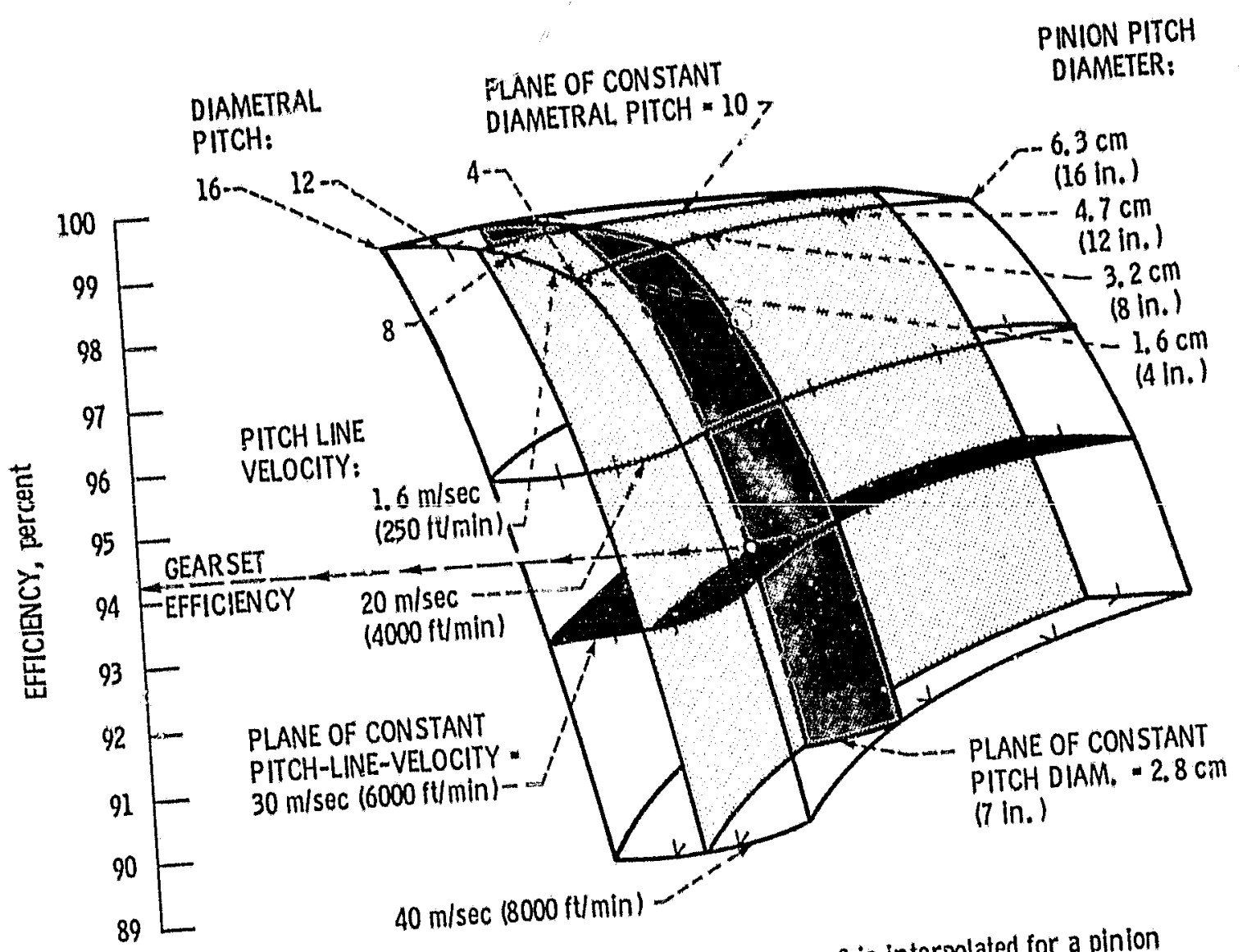
Figure 13. - Example of interpolation on a carpet plot. Figure 9 is interpolated for a pinion
ditec 